\title{
Analysis of the Global Pulses Market and Programs Encouraging Consumption of This Food
}

\begin{abstract}
The prevalence of diet-related diseases together with global population growth and the imbalance of ecosystems determine an urgent need to change existing dietary patterns and make food market more sustainable. A widely available alternative to food of animal origin are plant sources of protein, including pulses. The aim of this paper was to analyse the global pulses market and to review programs encouraging the increase of pulses consumption. The production and consumption of this food were analysed globally, regionally, and in selected countries using FAOSTAT data. The situation on the Polish market was presented additionally on the base of GUS (Central Statistical Office) data. Finally, the SWOT method was used to assess the market and indicate the possibility of giving up part of the meat consumption for pulses.
\end{abstract}

Key words: pulses, global market, production, consumption

JEL Classification: E21, Q11, Q13, I18

\section{Introduction}

Due to the public health situation, environmental issues and probability of global food insecurity worsening in the face of constant population growth the immediate challenge is to change dietary patterns and behaviours to more sustainable. Such a shift corresponding to environmental, health, social, economic and cultural aspects of food production, market and intake (FAO 2012, Willet et al. 2019). The main demand which meets all of those issues is the adoption of a more plant-based diet, especially in developed countries. This dietary pattern includes eating more vegetables, fruits, whole grains and pulses.

Pulses are an abundant source of a plant protein (20-35\%, on average) which can replace meat in a daily consumption and improve diet profile in populations with high rate of overweight and obesity (Kim et al. 2016). High content of carbohydrates (approx. 60\%) and dietary fibre qualify pulses low in glycaemic index. This has the effect of increasing the feeling of fullness, which promotes weight control, in particular among overweight or obese people ( $\mathrm{Li}$ et al. 2014). Research indicates that frequent consumers of pulses might have a better glycaemic control and blood LDL cholesterol level (Abeysekara 2016). Moreover the resistant starch that is dietary fibre's component nourishes the intestinal microbiota, which is called the second brain (Ridaura and Belkaid 2015). It affects the functioning of the human body, its physical and psychological characteristics. Pulses are rich in vitamins $\mathrm{B}$, especially folate (it content in chickpeas is higher than in other foods) as

${ }^{1}$ mgr inż., e-mail: agata_szczebylo@sggw.pl; https://orcid.org/0000-0002-4077-1673

${ }^{2}$ dr hab., https://orcid.org/0000-0001-8692-4383

${ }^{3} \mathrm{dr}$ inż., https://orcid.org/0000-0002-0535-2115

${ }^{4}$ mgr inż., https://orcid.org/0000-0003-0942-3336

1,2,3,4 Department of Food Market and Consumer Research, Institute of Human Nutrition Sciences WULS-SGGW, Nowoursynowska 159c, 02-776 Warsaw 
well as minerals such as phosphorus, potassium, calcium, iron, copper, zinc or manganese (Gawęcki and Woźniewicz 2010). All these characteristics make pulses nutrient-dense food and their higher intake is widely recommended. Despite the fact that pulses are a product known around the world it seems necessary to draw the attention of the younger generation of developed countries to this very diversified food group. The increasing popularity of vegetarian or vegan diets favours this trend, but the vast majority of people continue to increase the consumption of animal products, which is the result of economic development and an increasing income among the world populations (EUPHA 2017).

Increasing of pulses consumption has also economic and environmental significance. Their production is many times cheaper than meat, especially regarding highly water and soil efficiency. Legumes (the plants) have nitrogen-fixing ability, which can improve soil fertility resulting in the extending of farmland productivity without environmentally harmful fertilizers. The cultivation of legumes promotes biodiversity and creates a more diverse landscape for animals and insects, and decreases the risks of farmers face from environmental and market fluctuations. In this way they contribute to climate change mitigation and adaptation (Reckling et al 2015, FAO 2016a). Pulses are also of strategic importance in feeding the world, as economic benefits can translate into more sustainable agricultural systems and higher food security (FAO 2016). Pulses are a staple food in many traditional ethnic cuisines in developing countries as they are a powerful superfood with high economic accessibility (farmers can eat and/or sell their harvest) (FAO 2016, McDermott and Wyatt 2017). Pulses play a significant and diverse role in the agricultural systems and diets of underprivileged populations worldwide. They are ideal product for reducing poverty, improving human health and nutrition, and enhancing resilience of the ecosystem (Oluwafemi et al. 2017). It means that this food can be successfully used in greater amount in other high income nationalities.

All these aspects contributed to the announcement by the Food and Agriculture Organization of the United Nations (FAO) the International Year of Pulses (IYP) in 2016. The IYP 2016 aimed to heighten public awareness of the nutritional benefits of pulses as a part of sustainable food production and consumption targeted towards better food security and nutrition in the world (FAO 2016).

\section{Aim and methodology of study}

The aim of the study was to analyse global pulses market through the lens of the need to change dietary patterns for more sustainable ones. The results of the analysis of the FAO statistical data together with the review of secondary sources focused on initiatives promoting consumption of pulses were used to assess the market using the SWOT method. The data used for the analysis came from the FAOSTAT database. Data taken for the analysis of changes in the production of pulses as an aggregated items and as the crop structure of individual species regard to the years 1997-2017. It should be noted that the term pulses refers to dried seeds of legumes, i.e. the plants whose fruit is enclosed in a pod, so it exclude green peas and fresh beans which are classified as vegetables. Peanuts and soybean are also excluded from the group of pulses as they are used mainly for processing: soybean for oil and fodder production, and peanut for oil and peanut butter production (FAO 1994). In general pulses are used as both food and feed on a global level. Production 
data in this paper refer to both purposes of use (food and feed) while consumption data only to the supply of pulses aimed at the human population.

Data on consumption are provided by FAO Food Balance Sheets according to the latest available year 2013. The database shows food items for human consumption, along with how it is produced, used, imported/exported, and how it benefits the society (per capita supply). FBS estimate food consumption only from a food supply perspective and do not differentiate by diets consumed by different population groups, so it shows the consumption on the food balance level (Halicka et al. 2018).

The pulses market in Poland was analysed using data from Household Budget Surveys and Statistical Yearbooks of Agriculture provided by Central Statistical Office (GUS). Information on different initiatives promoting pulses consumption was obtained using the netography method. To summarise the results of our analysis the SWOT method was used.

\section{Results}

\section{Production of pulses}

Around 200 different legumes species are grown in the world, however according to the FAO classification of food categories, pulses cover 11 primary groups of species which are harvested solely for dry seeds and its derived products. There are: dry beans, dry broad beans, dry peas, chickpeas, dry cow peas, pigeon peas, lentils, bambara beans, vetches, lupins, pulses nes (not elsewhere specified), flour of pulses, and bran of pulses (the residues from the milling or working of pulses used as a fodder). Among these pulses groups the most important in human nutrition and trade worldwide are: beans, lentils, peas and chickpeas (FAO 1994).

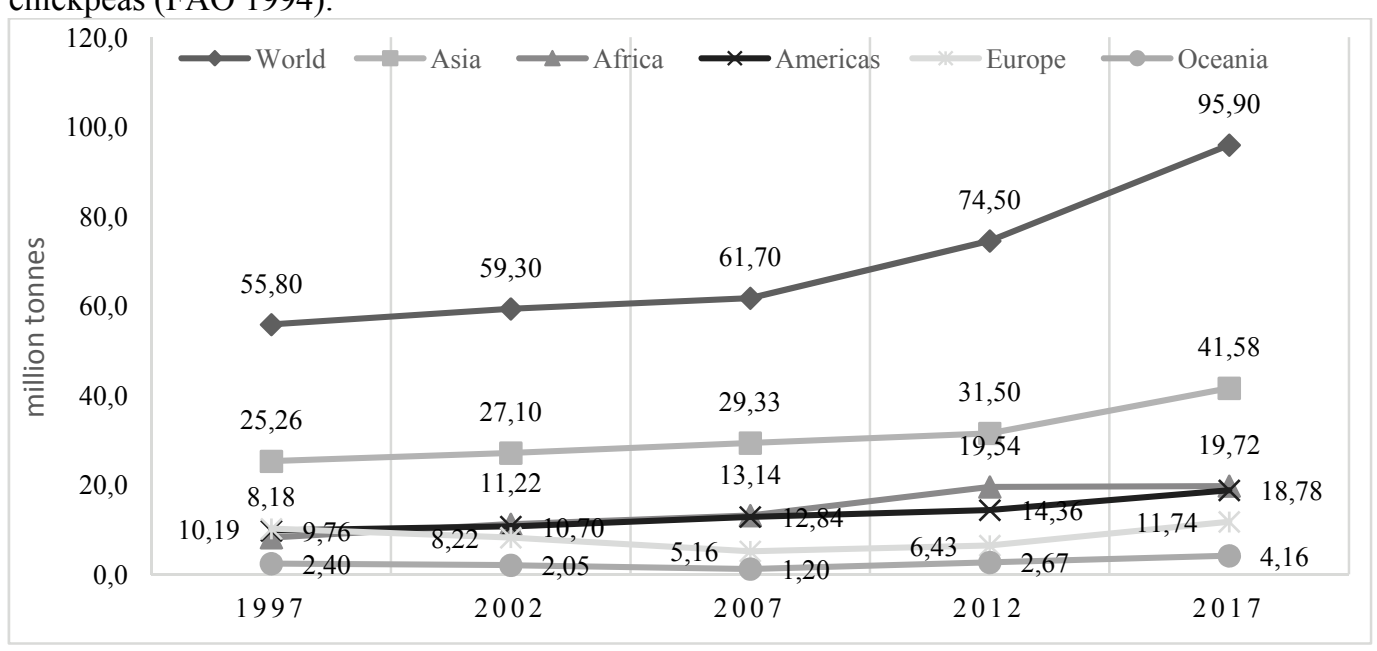

Fig. 1. Global pulses production in five-year period (for food and feed) in the years 1997-2017, by regions, million tonnes

Source: FAOSTAT Data Production of Crop, http://www.fao.org/faostat/en/\#data. 
According to FAOSTAT data the production of pulses in the world reached almost 96 million tonnes in 2017 (Fig. 1).

Globally, there was a period of stagnation in pulses production between 1997 and 2003 when the production has not exceeded 60 million tonnes and varied from 55,8 (1997) to 59.2 (2003) million tonnes (average annual growth rate was 0.1\%). In 2004, production amounted to 60.7 million tonnes and gradually grew in the consecutive years (except three years, which is understandable due to the dependence of harvest on weather fluctuations). In 2017, production reached 96 million tonnes, so since 2003 it increased by $62 \%$ (average annual growth rate was 3\%). The largest annual increase was recorded in 2017, as the harvests were $15 \%$ higher than in 2016. When analysing by regions, each year Asia represents the highest level of production with over $43 \%$ share in global production (in 2017), followed by Africa with $20 \%$ contribution and American regions with a very similar share. Europe's contribution in the global pulses production equals $12 \%$, and the share of $4 \%$ ranked Oceania on fifth place. The observed global increase in production was reached mainly due to the growth in Asia (Joshi and Rao 2016).

In the structure of the global pulses production dry beans account for the highest share of $33 \%$, followed by dry peas, chickpeas and lentils, which constituted 17,15 and $8 \%$, respectively. The analysis of data regarding particular types of pulses in 1997, 2007 and 2017 (Table 1.) shows that dry beans invariably remains the leading species in the global production, as well as in Asia, Africa and America regions. Over the years, there has been a steady increase in beans production, with the greatest growth for Africa (by 172\% in 2017 compared to 1997).

Table 1. Global production of pulses main species, 1997, 2007, and 2017, million tonnes

\begin{tabular}{|c|c|c|c|c|c|}
\hline & & Dry beans & Dry peas & Chickpeas & Lentils \\
\hline \multirow{3}{*}{ World } & 1997 & $16,5^{1)}$ & 11,9 & 8,3 & 2,8 \\
\hline & 2007 & 21,7 & 14,7 & 9,7 & 3,2 \\
\hline & 2017 & 31,4 & 16,2 & 14,8 & 7,6 \\
\hline \multirow{3}{*}{ Asia } & 1997 & 6,9 & 1,9 & 7,5 & 2,1 \\
\hline & 2007 & 10,1 & 1,9 & 8,5 & 2,1 \\
\hline & 2017 & $15,5 *$ & 2,6 & $10,8^{*}$ & 2,7 \\
\hline \multirow{3}{*}{ Africa } & 1997 & 2,5 & 0,3 & 0,2 & 0,07 \\
\hline & 2007 & 4,1 & 0,4 & 0,4 & 0,09 \\
\hline & 2017 & 6,8 & 0,6 & 0,7 & 0,20 \\
\hline \multirow{3}{*}{ Americas } & 1997 & 6,4 & 2,2 & 0,3 & 0,5 \\
\hline & 2007 & 7,1 & 3,8 & 0,4 & 0,9 \\
\hline & 2017 & 7,9 & 5,5 & 0,7 & $4,1^{*}$ \\
\hline \multirow{3}{*}{ Europe } & 1997 & 0,7 & $7,4 *$ & 0,09 & 0,03 \\
\hline & 2007 & 0,3 & 2,6 & 0,07 & 0,03 \\
\hline & 2017 & 1,1 & 7,1 & 0,60 & 0,27 \\
\hline \multirow{3}{*}{ Oceania } & 1997 & 0,04 & 0,4 & 0,2 & 0,04 \\
\hline & 2007 & 0,03 & 0,3 & 0,2 & 0,03 \\
\hline & 2017 & 0,04 & 0,4 & 0,2 & 0,20 \\
\hline
\end{tabular}

* The highest production of each species is marked with an asterisk

1) The highest production in a given year in a given region has been bolded

Source: FAOSTAT Data Production of Crop, http://www.fao.org/faostat/en/\#data.

However, the largest beans producer is Asia providing almost $50 \%$ of the global production in 2007 and 2017 (in 1997 more chickpeas than beans was produced). Two decades later, this region remains the world's largest producer of chickpeas, providing $73 \%$ 
of global production. In the case of dry peas, the largest production is recorded in Europe. It amounted to 7.4 and to 7.1 million tonnes in 1997 and 2017, respectively, accounting for $44 \%$ of world production in 2017 . The largest producer of lentils were the regions of America, which accounted for $54 \%$ of the global production. However, Americas became the leader in the decade 2007-2017, mainly thanks to Canadian production, while previously Asia was the largest producer of lentils.

The analysis of the data regarding pulses production demonstrated other important feature of this market, that the most of the global production volume comes from developing countries. Also more than $80 \%$ of world's pulses production is dedicated to meet a domestic demand (Miller Magazine 2017). Moreover this production is highly fragmented, as $90 \%$ comes from a small scale and small crop areas from 100 million local farmers (FAO 2016a). Of the top 5 countries with the highest pulses production, 4 are developing countries (Fig. 2). During the analysed period India was the biggest pulses producer, in 2017 followed by Canada, Myanmar, China and Nigeria. Total pulses production in India reached over 23 million tonnes in 2017, which constituted almost $1 / 4$ of the global production of this food. It was a huge increase comparing to 2007 with the production 14.8 million tonnes (55\% rise). However, India's production of pulses is the least efficient compared to the other four countries. India's yields are 2 times lower than in Canada, which is the second world producer of pulses and obtains the highest yields. Also in Nigeria, which is the fifth producer, yields are higher than in India by almost $25 \%$. Fragmentation of production results in lower efficiency, however, it is a more sustainable system and the new approach assumes reducing the difference in yield gaps on current cropland in a sustainable way (Willet et al. 2019). Considering that India, in order to satisfy the demand for pulses is also the largest importer of these food, the increase of pulses yield would help to improve food security in this country.

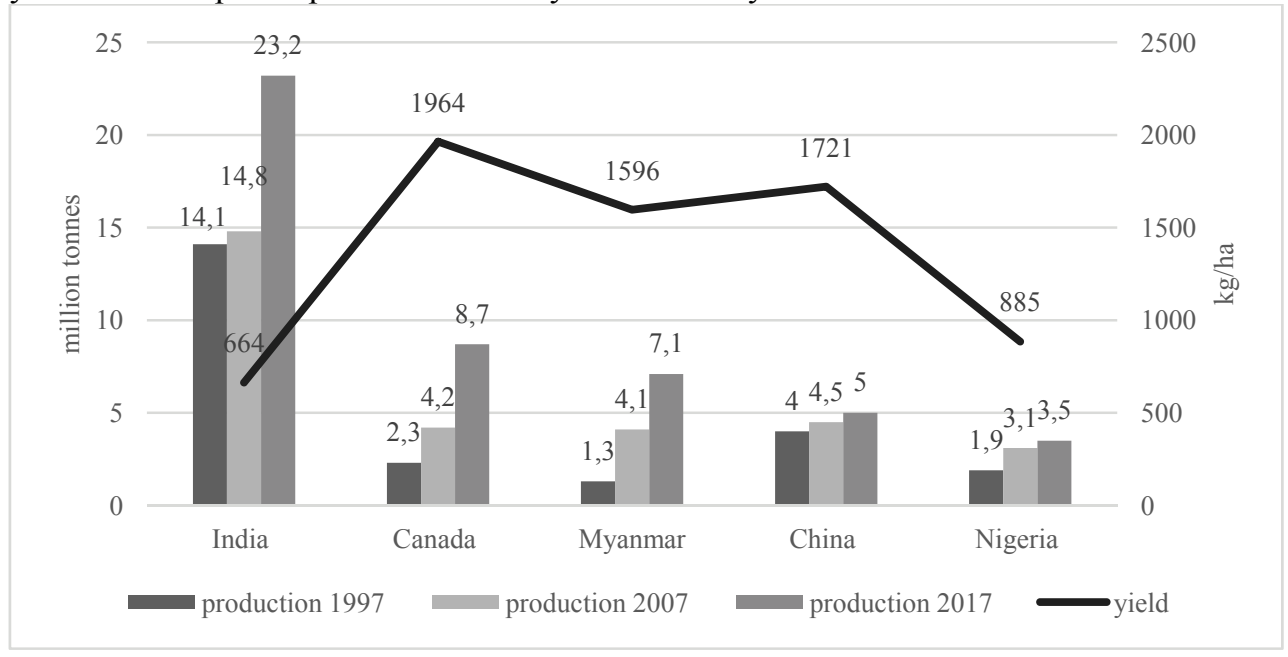

Fig. 2. Top 5 countries in pulses production (for food and feed) in 1997, 2007 and 2017 (million tonnes) and yield 2017 (kg/ha)

Source: FAOSTAT, Data Production of Crop, http://www.fao.org/faostat/en/\#data.

According to pulses production in Poland in the years 2000-2016 two periods can be determined: up to 2008, when the production level was lower than 60 thousand tonnes and 
exactly in this year was the lowest and amounted to 56.4 thousand tonnes, i.e. $40 \%$ less than in 2000. The following years were characterized by the constant growth and in 2016 production reached 219.2 thousand tonnes. Thus, it was nearly four times higher (by $289 \%$ ) than in 2008 (GUS 2001...2017). The vast majority of the production takes place on individual farms (over $90 \%$ in the current decade). Nearly half $(47.8 \%$ ) of pulses production in Poland is peas, followed by beans, which account for $28.8 \%$ of the harvest in 2017 (GUS 2018).

\section{Consumption of pulses}

When it comes to pulses consumption, FAO Food Balance Sheets show as a global average per capita pulses consumption has increased by $1.25 \mathrm{~kg}$ since 1997 and the average person consumed $7.2 \mathrm{~kg}$ of pulses in 2013. Much higher than the average and constantly growing was Africa's and Americas' consumption, in 2013 reaching 11.8 and $9.2 \mathrm{~kg} /$ capita, respectively (Fig. 3). The lowest consumption level was registered in the developed regions as Europe and Oceania and amounted to 2.6 and $2.1 \mathrm{~kg} /$ capita, respectively.

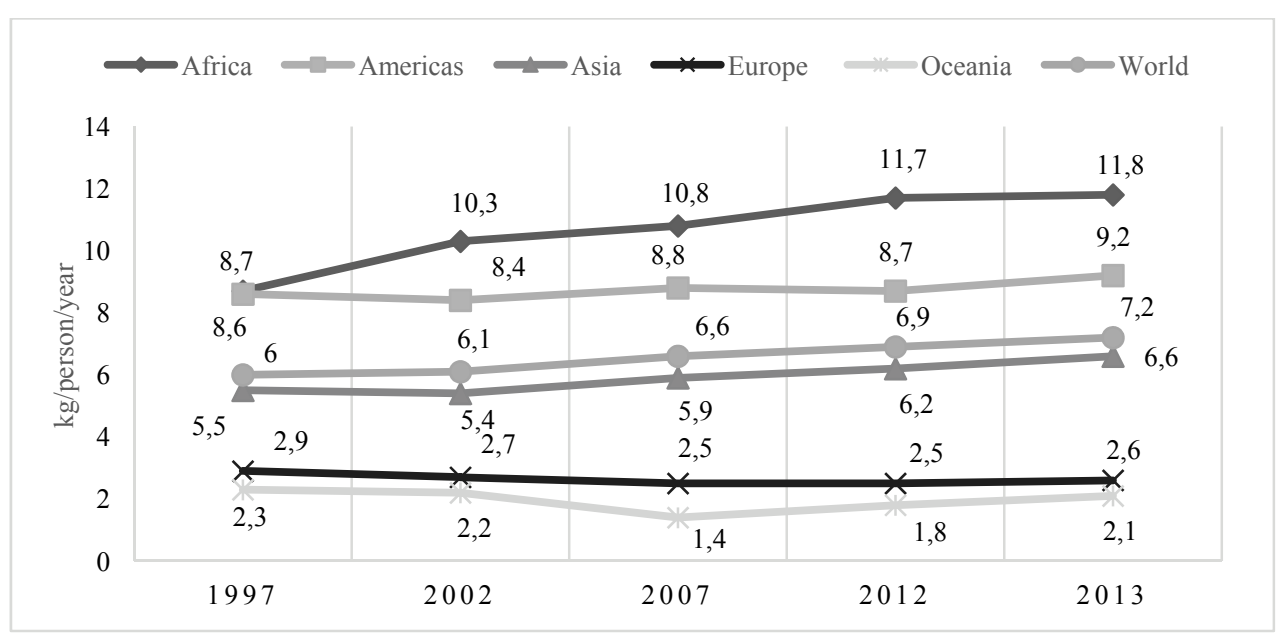

Fig. 3. World consumption of pulses in 1997-2013, by regions

Source: FAOSTAT, Food Balance Sheets, http://www.fao.org/faostat/en/\#data/FBS.

Taking into account particular countries, the highest pulses consumption at the level of $36 \mathrm{~kg} / \mathrm{capita} /$ year is recorded in such African countries as Niger and Rwanda. In India and Myanmar, it is about $14 \mathrm{~kg}$, and in Canada $12 \mathrm{~kg}$, which ranks first with the highest consumption level among the developed countries. Pulses are traditionally a significant source of protein in developing countries. World demand for pulses increases systematically since 2005 due to the dynamic population growth in Africa and Asia. Forecasts indicate that by 2050 a big deficit in pulses supply may occur in these regions as well as in Latin America (Joshi and Rao 2017). It is worth adding that for a relatively high average consumption of pulses in regions of America $(9.2 \mathrm{~kg} /$ person in 2013), there is a very large variation in consumption quantity among individual countries. In the US it is 
only $4.2 \mathrm{~kg}$, in South America 10.6, in Central America 12.9, and the largest in the Caribbean - almost $16 \mathrm{~kg} /$ person.

In Poland, according to the Central Statistical Office data obtaining in the frame of yearly household budget surveys, in the years 2007-2012 consumption of pulses was very low and amounted to $0.05-0.06 \mathrm{~kg} /$ person/month, i.e. $0.6 \mathrm{~kg}$ per year (Laskowski 2018). Since 2013 pulses are included in the group of dried vegetables and other processed vegetable products. The consumption of this food group has increased in the period 20132017 from 0.83 to $0.95 \mathrm{~kg} /$ person/month (GUS 2014...2018).

Own calculations regarding pulses consumption on the level of the Polish food balances (GUS 2001...2017) showed that in the years 2000-2016 two periods can be distinguished. In the first period the consumption was lower and fluctuated in the range from $2.1 \mathrm{~kg} /$ person in 2000/2001 farming year to $1.43 \mathrm{~kg} /$ person in 2006/2007. From 2008/09 consumption began to grow and in 2015/16 reached $3.87 \mathrm{~kg} /$ person. Balance sheets data cannot be directly compared to household survey data as balances are of estimated character and their compilation includes information on: the amount of domestic production of agricultural origin, import, export, stocks at producers' and in commercial outlets, and consumption of food products in households. However in contradiction to the household survey data they embrace food consumption in the gastronomy. It is worth noting that according to FAO's Food Balances the consumption of pulses in Poland in the years $2000-2013$ varied from $1.57 \mathrm{~kg}$ /capita in 2003 to $2.20 \mathrm{~kg}$ in 2007 . In the European Union the average consumption of pulses was $2.77 \mathrm{~kg} /$ capita. The lowest consumption, below $1 \mathrm{~kg} /$ person was observed in Latvia, Croatia and Germany, while the highest quantity of $8.66 \mathrm{~kg}$ was reached in Estonia. A high level of pulses consumption of around 5 $\mathrm{kg} /$ person was characterised by Greece, Italy, and Spain.

\section{Market overview and programs encouraging consumption}

According to Businessinsider's prognosis the global pulses market is expected to grow constantly during the period 2018-2022 (Business Insider 2018). It results from rising population in developing countries and constant growth of demand for pulses and their production volume. However also in a high-income part of the world a huge trend for pulses-based foods is observed. Business and food market is the fastest-suited to consumption trends and the biggest trend announced for 2019 is a vegetarian and vegan diet (Parker 2018, Banis 2018). A huge increase in the availability of pulses-based products is observed worldwide (foodnavigator.com). The most popular are flours, noodles and pastas, and different kinds of snacks (Kumar and Joshi 2014), e.g. extruded chips, roasted crunchy chickpeas, protein bars. Some of these products are suitable for consumers who follow the gluten-free diet. The pulses ingredients market is analysed by type - pulse flours, starch, protein, fibres and grits, by source - lentils, peas, beans, chickpeas, and by application food and beverages, feed and others. The forecast predicts the growth of the market which should reach 21.6 billion dollars by 2023 . Pulse ingredients are used in food products such as bakery goods, snacks, soups, sauces (Business Wire 2019). The huge part of the market are meat substitutes, which, however, mostly rely on soy. In spite of the constantly growing world soybean crops, the consumers concerns about consuming soybeans products can be observed (Lucht 2015). This is due to the unknown consequences of eating genetically modified plants (Tsatsakis 2017, Hilbeck 2015), and 97\% of global crops come from such 
seeds (ISAAA 2017). The American company Beyond Meat introduced to the market meat substitutes which are fully plant-based and a pea protein isolate was used as the main protein component. The company's flagship products are plant burgers and sausages. The main object of Beyond Meat was to create a product with the same sensory experience as when eating meat, thanks to which it has a chance to become a real equivalent of beef products. The company locates its products in stores in the meat section, which is a step towards a different, more sustainable consumer's perception of protein products (beyondmeat.com). The company is growing rapidly and its offer was available in 50 countries in 2018 (Nunes 2018).

However, to achieve this desirable shift towards a more sustainable dietary pattern, consumption of plant-based products should increase as a result of changes in the entire food system and not only due to market novelties. Therefore, pulses promotion is carried out in different ways by various institutions and groups of interests, including the politicians and consumers. In addition to the broad initiatives of IYP 2016 many local programs have been undertaken to encourage consumption and production of pulses. The main activities undertaken by FAO were information and education website, publications, infographics, communication in social media. Local activities mainly covered such events as: conferences, symposia, seminars, festivals, culinary competitions, exhibitions, culinary workshops, food donations. In Poland, only one officially registered activity was carried out as a part of the IYP celebration, i.e. it was 'The tastiest pulse dish competition' organized by the Gastronomic School in Kalisz (FAO 2019).

In order to sustain the effects of IYP the UN General Assembly in 2018 officially designated 10 February as a World Pulses Day to "reaffirm the contribution of pulses for sustainable agriculture and achieving the 2030 Agenda" (UNGA 2018). The celebrations was leading by the Global Pulse Confederation (GPC), a non-profit association for the pulse industry supply chain, which is sponsored by the biggest world pulses producers, with headquarters located in Dubai (GPC 2019).

The campaigns in the US and Canada focus on pulses consumption promotion and in many cases are driven by producers or business associations (also GPC). In the United States the program "USA Pulses" is managed by the USA Dry Pea and Lentil Council and the American Pulse Association in cooperation with Pulses Canada, which represent the dry peas, lentil, dry bean and chickpea industry in both countries. USA Pulses launched a "Half-Cup Habit" campaign, which is a pledge form of the promotion of the growth of pulses intake in the daily diet. The main message is to increase consumption to 1.5 cup per week or half cup 3 times per week, what is recommended for the American population by the ministry of agriculture - USDA (pulses.org/nap/half-cup-habit). The campaign website contains basic information about pulses, cooking tips, recipes easy to use for individuals, as well as extended guide for foodservice and industry.

In Canada, lentils.org website similarly focuses on culinary tips that could facilitate the incorporation of lentils into daily nutrition. It is led by local farmer organization Saskatchewan Pulse Growers, as this province is the main area of Canadian lentils production and exporting (www.lentils.org). The global leader in pulses production, and particularly lentils is the Canadian company AGT Food and Ingredients, whose CEO Murad Al-Katib received the title of the Entrepreneur of the Year 2017 given by EY (Ernst \& Young, a multinational professional services firm) (Bouw 2017; EY 2017).

In the European Union, the approach is completely different. The activities mainly focuses on the Research \& Development issues in relation to leguminous crops and their 
inclusion as a part of sustainable agriculture. European Commission funded some projects, e.g. Legume Futures (Legume-supported cropping systems for Europe), LEGUVAL (use of co-products and by-products of processed legumes production), Eurolegume (Enhancing of legumes growing in Europe through sustainable cropping for protein supply for food and feed) or LEGATO (LEGumes for the agriculture of Tomorrow). Currently ongoing project "Transition paths of sustainable legume based system in Europe" (TRUE, 2017-2022) is driven by 24 partnership institutions, which aims to identify the best routes to "increase sustainable legume cultivation and consumption across Europe" (True Project). The project deals with broad range of issues, including environment, economics, nutrition and product development, markets and consumers, policy and governance, consumers and market. In Poland, programs and projects also are mainly focused on more sustainable production methods and cooperation of farmers producing pulses for animal feed (Program Wieloletni...). The analysed initiatives are presented in the table 2 .

Table 2. The overview of programs encouraging consumption of pulses

\begin{tabular}{|c|c|c|c|}
\hline Campaign/Program & Leader & Scope and target groups & Actions \\
\hline $\begin{array}{l}\text { International Year of } \\
\text { Pulses } 2016\end{array}$ & $\begin{array}{l}\text { Food and Agriculture } \\
\text { Organization }\end{array}$ & $\begin{array}{l}\text { Global } \\
\text { Local } \\
\text { Consumers } \\
\text { Policymakers } \\
\text { Public sector } \\
\text { Private Entities } \\
\text { Research centers } \\
\text { Educational institutions } \\
\text { Media }\end{array}$ & $\begin{array}{l}\text { - } \text { website } \\
\text { - } \text { publications } \\
\text { - infographics } \\
\text { - communication in social } \\
\text { media } \\
\text { - conferences, symposia, } \\
\text { seminars, festivals, culinary } \\
\text { competitions, exhibitions } \\
\text { - } \text { political declarations }\end{array}$ \\
\hline World Pulses Day & $\begin{array}{l}\text { - Global Pulse } \\
\text { Confederation } \\
\text { (GPC) } \\
\text { - United Nations }\end{array}$ & $\begin{array}{l}\text { Global } \\
\text { Local } \\
\text { Consumers } \\
\text { NGOs } \\
\text { Public sector } \\
\text { Private Entities } \\
\text { Educational institutions } \\
\text { Media } \\
\end{array}$ & $\begin{array}{l}\text { - culinary workshops } \\
\text { - food donations } \\
\text { - } \text { seminars } \\
\text { - } \text { social media campaigns } \\
\text { (e.g. make } 1 / 2 \text { your protein } \\
\text { a plant plant protein) } \\
\text { - school visits }\end{array}$ \\
\hline $\begin{array}{l}\text { USA Pulses - } \\
\text { pulses.org/half-cup } \\
\text { habit }\end{array}$ & $\begin{array}{l}\text { - USA Dry Pea and } \\
\text { Lentil Council } \\
\text { - American Pulse } \\
\text { Association } \\
\text { - Pulses Canada } \\
\end{array}$ & $\begin{array}{l}\text { Local } \\
\text { Consumers } \\
\text { Foodservice } \\
\text { Industry } \\
\end{array}$ & $\begin{array}{l}\text { - consumer-faced website } \\
\text { - pledge program } \\
\text { - foodservice information }\end{array}$ \\
\hline Lentils.org & $\begin{array}{l}\text { Saskatchewan Pulse } \\
\text { Growers }\end{array}$ & $\begin{array}{l}\text { Local } \\
\text { Consumers }\end{array}$ & - consumer-faced website \\
\hline $\begin{array}{l}\text { - Legume Futures } \\
\text { - LEGUVAL } \\
\text { - Eurolegume } \\
\text { - } \text { LEGATO } \\
\text { - TRUE }\end{array}$ & European Commission & $\begin{array}{l}\text { Local } \\
\text { Research centres } \\
\text { Agriculture sector }\end{array}$ & - $\mathrm{R} \& \mathrm{D}$ programs \\
\hline
\end{tabular}

To sum up the situation on the global pulses market in a methodical way, the SWOT analysis is presented in Table 3 . 
Table 3. The SWOT analysis of a global pulses market

\begin{tabular}{|c|c|}
\hline Strengths & Weaknesses \\
\hline $\begin{array}{l}\text { - Mature world market } \\
\text { - Growing demand and production } \\
\text { - High nutritional value and health benefits of pulses } \\
\text { - Environmentally friendly production } \\
\text { - Development of innovative, pulses-based products }\end{array}$ & $\begin{array}{l}\text { - Small crop areas and small scale of } \\
\text { production in developing countries } \\
\text { - Domination of big exporters and producers } \\
\text { from developed countries } \\
\text { - Low consumption in developed countries }\end{array}$ \\
\hline Opportunities & Threats \\
\hline $\begin{array}{l}\text { - Programs encouraging consumption and cultivation } \\
\text { - Sustainable agriculture programs in developed and } \\
\text { developing countries } \\
\text { - Trends in nutrition towards plant-based diets, food } \\
\text { intolerances, esp. of animal origin, gluten-free } \\
\text { - Growing appreciation of the consumers for high protein } \\
\text { grains and seeds } \\
\text { - Increase of consumer demand for pulses-based products } \\
\text { and growing demand from food industry, eg.production } \\
\text { of ready-to-eat food }\end{array}$ & $\begin{array}{l}\text { - High competitiveness of soybean } \\
\text { - The acquisition of a large part of the market } \\
\text { by corporations and mass production - risk } \\
\text { for local and small scale producers } \\
\text { - Development of highly processed products } \\
\text { may have adverse (unbeneficial) effect for } \\
\text { consumer health and environment }\end{array}$ \\
\hline
\end{tabular}

Source: see table

\section{Conclusions}

The pulses market is expected to grow steadily due to the constant and predictable growth in global demand and the mounting consumer inclination towards healthy and nutritious food. Apart from being a highly rich source of protein, pulses provide high levels of dietary fibre, vitamins, minerals, phytochemicals and complex carbohydrates. The majority of the global population relies on pulses as a staple food. However, their consumption differs from region to region depending on the dietary patterns, availability and prevailing conditions.

Pulses are also important ecological solution for an agricultural due to their ability of bonding nitrogen from the air. Legumes crop and pulses production are fragmented, which is perceived as more sustainable and providing better living conditions and food security in developing countries.

As those crops have a beneficial effect on the environment well as improve the economic situation of farmers and local communities, their cultivation is supported by governments and other public and non-public entities all around the world. The progressing importance of recommendations for sustainable development and striving to meet Sustainable Development Goals by 2030 contribute in pulses production growth. An increase in the consumption of pulses and pulses-based products and a simultaneous reduction in the consumption of meat and meat products is essential to achieve at least several of these goals. It regards especially to high-income countries, but it is also necessary to closely observe the development of consumption in Asian countries. Their dynamic economic growth results in a change in dietary patterns and growing consumption of meat to the detriment of traditional staple food of these countries.

Initiatives promoting the consumption of pulses focus on their exceptional nutritional value and health benefits of plant-based diets both for the people and the planet. Greater consumer awareness and responsible food choices together with vegetarian trends, which are mainly observed among younger generations are an opportunity for further development 
of the pulses market. The dynamic growth of the pulses-based processed food industry can be already observed and is the result of urbanization and changing lifestyles. However consumption of highly processed products is not recommended from the point of view of sustainable diet recommendations. Therefore, an increase in consumer awareness in developed countries is still required, in terms not only the health issues of consumed products but also related to the functioning of the entire food system. Programs aimed at encouraging consumption of pulses are an important element of change towards sustainable diets and the cooperation of specialists, entrepreneurs and policymakers is essential for the introduction of effective and lasting transformation.

\section{References}

Abeysekara, S., Chilibeck, P.D., Vatanparast, H., Zello, G.A. (2012). A pulse-based diet is effective for reducing total and LDL-cholesterol in older adults. British Journal of Nutrition, 108, ss. 103-S110.

Banis, D. (2018). Everything is ready to make 2019 "The Year of the Vegan". Are you? (Available on:) forbes.com/sites/davidebanis/2018/12/31/everything-is-ready-to-make-2019-the-year-of-the-vegan-areyou/\#461d6eee57df (Access date: January 2019)

Beyond Meat (2019) (Available on:) beyondmeat.com (Access date: March 2019)

Program Wieloletni 2016-2020 (Available on:) bialkoroslinne.iung.pl (Access date: January 2019)

Bouw, B. (2017). Murad Al-Katib: 'As Canadians, our knowledge of diversity ... gives us an advantage in international business' (Available on:) theglobeandmail.com/report-onbusiness/careers/management/murad-al-katib-as-canadiansour-knowledge-of-diversity-gives-us-anadvantage-in-international-business/article36587317/ (Access date: January 2019)

Business Insider (2018). Global Pulses Market Report 2018-2022 - Beans Segment Expected to Grow Steadily Due to the Increasing Demand Across the World. Available on: markets.businessinsider.com/news/stocks/global-pulses-market-report-2018-2022-beans-segment-expectedto-grow-steadily-due-to-the-increasing-demand-across-the-world-1018710439. Access date: January 2019.

Business Wire (2019): Global Pulse Ingredients Market Forecast to 2023. Available on: www.apnews.com/Business\%20Wire/058a890c297141d38a8feed0924a1a7b. Access date: March 2019.

Calles, T., del Castello, R., Baratelli, M., Xipsiti, M., Navarro, D.K. (2019). The International Year of Pulses Final report. FAO.

Definition and classification of commodities. Pulses and derived products. (1994) FAO. Available on: http://www.fao.org/es/faodef/fdef04e.html. Access date: May 2018.

EY (2017). Murad Al-Katib of AGT Food and Ingredients Inc. from Canada named EY World Entrepreneur Of The Year 2017. Available on: ey.com/ca/en/newsroom/news-releases/2017-murad-al-katib-of-agt-food-andingredients-inc-from-canada-named-ey-world-entrepreneur-of-the-year-2017. Access date: May 2018.

Gawęcki, J., Woźniewicz, M. (2010). Produkty spożywcze jako źródło składników odżywczych. IN: Gawęcki J. (ed.) Żywienie człowieka T.1 Podstawy nauki o żywieniu (p. 356-357). Warszawa.

GPC (2019) (Available on:) globalpulses.com (Access date: January 2019)

Halicka, E., Rejman, E., Kaczorowska, J. (2018). Changes in EU Food Supply and the Activities of the European Platform for Action on Diet, Physical Activity and Health. Problems of World Agriculture, 18(4), 175-182.

Healthy and Sustainable Diets for European Countries. (2017) EUPHA.

Hilbeck, A., Binimelis, R, Defarge, N. et al. (2015). No scientific consensus on GMO safety. Environmental Science Europe, 27: 4

Household budget survey in 2014-2017. (2015-2018a). GUS

Household Budget Surveys 2014...2017 (2015-2018). GUS

ISAAA. (2017). Global Status of Commercialized Biotech/GM Crops in 2017: Biotech Crop Adoption Surges as Economic Benefits Accumulate in 22 Years. ISAAA Brief No. 53. ISAAA: Ithaca, NY.

Joshi, P.K., Parthasarathy Rao, P. (2016). Global and Regional Pulse Economies Current Trends and Outlook. IFPRI

Joshi, P.K., Parthasarathy Rao, P. (2017). Global pulses scenario: status and outlook. Annals of The New York Academy of Sciences, 1392, 6-17.

Kim, S.J., de Souza, R.J., Choo, V.L., Ha, V., Cozma, A.I., Chiavaroli, L., Mirrahimi, A., Blanco Mejia, S., Di Buono, M., Bernstein, A., Leiter, L.A., Kris-Etherton, P.M., Vuksan, V., Beyene, J., W.C. Kendall, C., 
Jenkins, D.JA., Sievenpiper, J. (2016). Effects of dietary pulse consumption on body weight: a systematic review and meta-analysis of randomized controlled trials. American Journal of Clinical Nutrition, 103, 1213-23.

Laskowski, W. (2018). KOiEK consumption service: data from individual results of the CSO Household Budget Surveys in 2007...2012. Available on: waclaw_laskowski.users.sggw.pl/spozycie.htm. Access date: December 2018

Lentils.org (2019). Available on: lentils.org. Access date: December 2018.

Li, S.S., W.C. Kendall, C., de Souza, R.J., Jayalath, V.H., Cozma, A.I., Ha V., Mirrahimi, A., Chiavaroli, L., S.A. Augustin, L., Blanco Mejia, S., Leiter, L.A., Beyene, J., Jenkins, D.J.A., Sievenpipe, J.L. (2014). Dietary Pulses, Satiety and Food Intake: A Systematic Review and Meta-analysis of Acute Feeding Trials. Obesity, 22, 1773-1780.

Lucht J. M. (2015). Public Acceptance of Plant Biotechnology and GM Crops. Viruses, 7(8), 4254-81.

McDermott J., Wyatt A.J. (2017). The role of pulses in sustainable and healthy food systems. Annals of The New York Academy of Sciences, 1392, 30-42.

Miller Magazine (2017). Available on: millermagazine.com/english/world-grain-and-pulses-market-2/. Access date: January 2019.

Nunes K. (2018). Beyond Meat files i.p.o. to fuel growth. Available on: foodbusinessnews.net/articles/12898beyond-meat-files-ipo-to-fuel-growth. Access date: January 2019.

Oluwafemi A. A., Njobeh P.B., Adebiyi J. A., Gbashi S., Phoku J.Z., Kayitesi E. (2017). Fermented Pulse-Based Food Products in Developing Nations as Functional Foods and Ingredients. IN: Chávarri Hueda M. (ed.) Functional Food Improve Health through Adequate Food. TECNALIA Research \& Innovation 2017.

Parker J. (2018). The world in 2019. The year of the vegan. The Economist. Available on: worldin2019.economist.com/theyearofthevegan?utm source=412\&utm medium=COM. Access date: January 2019.

Pulses. Nutritious seeds for a sustainable future. (2016). FAO

Pulses.org. Available on: pulses.org/nap/half-cup-habit/. Access date: January 2019.

Reckling, M., Hecker, J-M., Bergkvist, G., Watson, C.A., Zander, P., Schlafke, N., Stoddard, F.L., Eory, V., Topp, C.F.E., Maire, J. and Bachinger, J. (2015). A cropping system assessment framework - evaluating effects of introducing legumes into crop rotations. European Journal of Agronomy, 76, 186-197.

Ridaura, V., Belkaid, Y. (2015). Gut Microbiota: The Link to Your Second Brain. Cell, 161, 193-194.

Soils and pulses. Symbiosis for life. (2016a). FAO

Statistical Year of Agriculture 2000_..2016. (2001...2017). GUS

Statistical Year of Agriculture 2017 (2018). GUS

Sustainable diets and biodiversity. Directions and solutions for policy, research and action. (2012). FAO

True Project. Available on: true-project.eu. Access date: January 2019.

Tsatsakis, A.M., Nawaz, M.A., Tutelyan, V.A. et al. (2017). Impact on environment, ecosystem, diversity and health from culturing and using GMOs as feed and food. Food and Chemical Toxicology, 107, 108-121.

UN General Assembly (UNDA) (2019). World Pulses Day, A/RES/73/251, 73/251, 1-2.

Willett, W., Rockström, J., Loken, B., Springmann, M. et.al. (2019). Food in the Anthropocene: the EAT-Lancet Commission on healthy diets from sustainable food systems. Lancet, 393, 447-92.

\section{For citation:}

Szczebyło A., Rejman K., Halicka E., Jackowska M. (2019). Analysis of the Global Pulses Market and Programs Encouraging Consumption of This Food. Problems of World Agriculture, 19(3), 85-96; DOI: $10.22630 /$ PRS.2019.19.3.49 